\title{
Interleukin 17D Enhances the Developmental Competence of Cloned Pig Embryos by Inhibiting Apoptosis and Promoting Embryonic Genome Activation
}

\author{
Xiao Wu ${ }^{1,2,3, \dagger}$, Huaxing Zhao ${ }^{1,2,3,+}$, Junkun Lai 1,2,3, Ning Zhang ${ }^{1,2,3}$, Junsong Shi ${ }^{4}$, Rong Zhou ${ }^{4}$, Qiaoyun Su ${ }^{4}$, \\ Enqin Zheng ${ }^{1,2,3}$, Zheng Xu ${ }^{1,2,3}$, Sixiu Huang ${ }^{1,2,3}$, Linjun Hong ${ }^{1,2,3} \mathbb{D}$, Ting Gu 1,2,3(D), Jie Yang ${ }^{1,2,3}$, \\ Huaqiang Yang ${ }^{1,2,3} \mathbb{D}^{\text {, }}$, Gengyuan Cai ${ }^{1,2,3}$, Zhenfang $\mathrm{Wu}^{1,2,3,5, *}$ and Zicong $\mathrm{Li}^{1,2,3,5, *}$ \\ check for \\ updates \\ Citation: Wu, X.; Zhao, H.; Lai, J.; \\ Zhang, N.; Shi, J.; Zhou, R.; Su, Q.; \\ 1 National Engineering Research Center for Breeding Swine Industry, South China Agricultural University, \\ Guangzhou 510642, China; wuxiao5901@stu.scau.edu.cn (X.W.); zhaohuaxing2020@163.com (H.Z.); \\ junkun_lai@163.com (J.L.); zn20182024018@163.com (N.Z.); eqzheng@scau.edu.cn (E.Z.); \\ stonezen@scau.edu.cn (Z.X.); sxhuang815@scau.edu.cn (S.H.); linjun.hong@scau.edu.cn (L.H.); \\ tinggu@scau.edu.cn (T.G.); jieyang2012@hotmail.com (J.Y.); yangh@scau.edu.cn (H.Y.); \\ cgy0415@163.com (G.C.) \\ 2 Department of Animal Genetics, Breeding and Reproduction, College of Animal Science, \\ Guangzhou 510642, China \\ 3 Guangdong Provincial Key Laboratory of Agro-Animal Genomics and Molecular Breeding, South China \\ Agricultural University, Guangzhou 510642, China \\ 4 Guangdong Wens Pig Breeding Technology Co., Ltd., Yunfu 527499, China; junsongstone@126.com (J.S.); \\ zr326068732@163.com (R.Z.); 13437867576@163.com (Q.S.) \\ 5 State Key Laboratory for Conservation and Utilization of Subtropical Agro-Bioresources, South China \\ Agricultural University, Guangzhou 510642, China \\ * Correspondence: wzfemail@163.com (Z.W.); lizicong@scau.edu.cn (Z.L.) \\ + These authors made equal contribution to this work.
} Zheng, E.; Xu, Z.; Huang, S.; et al. Interleukin 17D Enhances the Developmental Competence of Cloned Pig Embryos by Inhibiting Apoptosis and Promoting Embryonic Genome Activation. Animals 2021, 11, 3062. https://doi.org/10.3390/ ani11113062

Academic Editor: Luisa Bogliolo

Received: 6 August 2021

Accepted: 20 October 2021

Published: 26 October 2021

Publisher's Note: MDPI stays neutral with regard to jurisdictional claims in published maps and institutional affiliations.

Copyright: (c) 2021 by the authors. Licensee MDPI, Basel, Switzerland. This article is an open access article distributed under the terms and conditions of the Creative Commons Attribution (CC BY) license (https:/ / creativecommons.org/licenses/by/ $4.0 /)$.
Simple Summary: The cloning technique is important for animal husbandry and biomedicine because it can be used to clone superior breeding livestock and produce multipurpose genetically modified animals. However, the success rate of cloning currently is very low due to the low developmental efficiency of cloned embryos, which limits the application of cloning. The low developmental competence is related to the excessive cell death in cloned embryos. Interleukin 17D (IL17D) is required for the normal development of mouse embryos by inhibiting cell death. This study aimed to investigate whether IL17D can improve cloned pig embryo development by inhibiting cell death. Addition of IL17D protein to culture medium decreased the cell death level and improved the developmental ability of cloned pig embryos. IL17D treatment enhanced cloned pig embryo development by regulating cell death-associated gene pathways and promoting genome-wide gene expression, which is probably via up-regulating the expression of a gene called GADD45B. This study provided a new approach to improve the pig cloning efficiency by adding IL17D protein to the culture medium of cloned pig embryos.

Abstract: Cloned animals generated by the somatic cell nuclear transfer (SCNT) approach are valuable for the farm animal industry and biomedical science. Nevertheless, the extremely low developmental efficiency of cloned embryos hinders the application of SCNT. Low developmental competence is related to the higher apoptosis level in cloned embryos than in fertilization-derived counterparts. Interleukin 17D (IL17D) expression is up-regulated during early mouse embryo development and is required for normal development of mouse embryos by inhibiting apoptosis. This study aimed to investigate whether IL17D plays roles in regulating pig SCNT embryo development. Supplementation of IL17D to culture medium improved the developmental competence and decreased the cell apoptosis level in cloned porcine embryos. The transcriptome data indicated that IL17D activated apoptosis-associated pathways and promoted global gene expression at embryonic genome activation (EGA) stage in treated pig SCNT embryos. Treating pig SCNT embryos with IL17D up-regulated expression of $G A D D 45 B$, which is functional in inhibiting apoptosis and promoting EGA. Overexpression of GADD45B enhanced the developmental efficiency of cloned pig embryos. 
These results suggested that IL17D treatment enhanced the developmental ability of cloned pig embryos by suppressing apoptosis and promoting EGA, which was related to the up-regulation of GADD45B expression. This study demonstrated the roles of IL17D in early development of porcine SCNT embryos and provided a new approach to improve the developmental efficiency of cloned porcine embryos.

Keywords: SCNT; porcine; IL17D; apoptosis; EGA

\section{Introduction}

Somatic cell nuclear transfer (SCNT) technique, also called cloning, is important for animal husbandry, biotechnology, biopharmacy and biomedicine because it can be used to clone superior breeding livestock [1,2] and produce multipurpose genetically modified animals [3-5]. However, the developmental efficiency of SCNT embryos is extremely low [6-9], which limits the practical application of cloning.

So far, a broad spectrum of research has characterized the biological, molecular and epigenetic determinants of mammalian SCNT embryo development. The afore-indicated determinants involve: (1) the origin of nuclear donor cells [10-14], (2) the quality of nuclear recipient oocytes determined by the parameters related to meiotic, epigenomic and cytoplasmic maturity $[15,16]$, (3) the methods used to stimulate the embryo-specific developmental program of enucleated oocytes [17-20], (4) the incidence of programmed cell apoptosis in in vitro-cultured nuclear donor cells and cloned embryos [21-23], (5) the intergenomic communication between nuclear DNA and mitochondrial DNA in cloned embryos [24-29], and (6) the capacity of donor cell nuclei to be reprogrammed in cloned embryos [30-33].

Apoptosis is one of the major reasons that affects cloned embryo development. Many studies have shown that the cell apoptosis level in SCNT embryos is higher than that in fertilization-derived counterparts [34-36]. Treatment with anti-oxidative molecules, such as vitamin C [37], vitamin E [38], and melatonin [39,40], improve cloned embryo development by inhibiting apoptosis. Cytokines, such as IGF1 [41] and CSF2 [42,43], also regulate apoptosis-related genes to increase the developmental rate of SCNT embryos. In addition, small RNAs, such as miR-101-2 [44] and miR-449b [45], decrease apoptosis to enhance the developmental efficiency of SCNT embryos.

Interleukin 17D (IL17D) is a cytokine that plays critical roles in mouse early embryo development by regulating apoptosis-associated pathways [46]. In fertilization-produced mouse embryos, IL17D expression is naturally up-regulated during 2-cell to 4-cell stage, and the inhibition of IL17D transcription impairs embryo development by increasing apoptosis. Meanwhile, supplementation of IL17D rescues embryonic developmental defects caused by the inhibition of IL17D expression.

The purpose of this study was to investigate whether IL17D plays roles in regulating pig SCNT embryo development. We demonstrated that the addition of IL17D to the culture medium increased the developmental ability of cloned porcine embryos via modulating apoptosis-relevant pathways and global gene expression.

\section{Materials and Methods}

\subsection{Ethics Statement}

This study was performed in accordance with the "Guidelines with Respect to Caring for Laboratory Animals" issued by the Ministry of Science and Technology of China. The animal experimental protocol was approved by the Institutional Animal Care and Use Committee of South China Agricultural University. All efforts were made to minimize the suffering of animals tested. 


\subsection{Medium and Reagents}

All the chemicals used in this study were procured from Sigma-Aldrich Company (MO, USA) unless otherwise mentioned.

\subsection{In Vitro Oocyte Maturation}

Porcine ovaries were collected from a local slaughterhouse and transported to the laboratory in $0.9 \%(w / v) \mathrm{NaCl}$ solution supplemented with penicillin-G $(100 \mathrm{IU} / \mathrm{mL})$ and streptomycin sulfate $(100 \mathrm{mg} / \mathrm{L})$ at $30-35^{\circ} \mathrm{C}$. Follicular fluid containing cumulus-oocyte complexes (COCs) was aspirated from 3-6 mm diameter antral follicles by using an 18gauge needle and syringe. COCs with at least three layers of compact cumulus cells and a homogenous cytoplasm were selected from follicle fluid and incubated with in vitro maturation medium [47] at $38.5^{\circ} \mathrm{C}$ with $5 \% \mathrm{CO}_{2}$ for $42-44 \mathrm{~h}$. Matured COCs were freed from cumulus cells by repeated pipetting in Dulbecco's phosphate-buffered saline (DPBS) (Gibco, Grand Island, NY, USA) containing $1 \mathrm{mg} / \mathrm{mL}$ hyaluronidase. Oocytes with uniform cytoplasm, round cell morphology, and clearly visible polar body were selected as mature oocytes for subsequent experiments.

\subsection{In Vitro Fertilization}

Porcine semen was purchased from a local animal husbandry company. The sperm density was adjusted to $2 \times 107 / \mathrm{mL}$ with modified Tris-buffered medium(mTBM) [48] for capacitation. The in vitro mature oocytes were washed with mTBM and transferred to a four-well plate with $40-50$ oocytes and $500 \mu \mathrm{L}$ mTBM per well. The capacitated semen $(50 \mu \mathrm{L})$ was added to obtain $1 \times 106$ sperm per well. After incubating at $38^{\circ} \mathrm{C}$ for $6 \mathrm{~h}$, the fertilized eggs were washed with DPBS supplemented with $1 \mathrm{mg} / \mathrm{mL}$ BSA to remove the sperm on the surface. The eggs were then transferred to PZM-3 medium [49] and cultured in an incubator at $38.5^{\circ} \mathrm{C}$ and $5 \% \mathrm{CO}_{2}$. Cleavage rate, blastocyst rate, and total cell number of blastocysts were calculated at 48 and $144 \mathrm{~h}$.

\subsection{Somatic Cell Nuclear Transfer}

Porcine fetal fibroblasts were cultured in DMEM with $10 \%$ of FBS at $38.5{ }^{\circ} \mathrm{C}$ and $5 \%$ $\mathrm{CO}_{2}$. When the cells reached a confluence of $90-100 \%$, they were digested with trypsin and resuspended in in vitro manipulation medium for later use. Mature oocytes were denucleated by blind aspiration. One donor cell was injected through the enucleated incision into the perivitelline space of each enucleated oocyte. Reconstituted embryos were cultured in PZM- 3 at $38.5^{\circ} \mathrm{C}$ for $4 \mathrm{~h}$ and $5 \% \mathrm{CO}_{2}$. The reconstructed embryos were activated in the fusion solution [1] through two direct current pulses of $150 \mathrm{~V} / \mathrm{mm}$ for 50 $\mathrm{ms}$. The reconstituted embryos were transferred to PZM-3 and cultured in an incubator at $38.5{ }^{\circ} \mathrm{C}$ and $5 \% \mathrm{CO}_{2}$. The numbers of cleaved embryos and blastocysts were calculated at $48 \mathrm{~h}$ and $144 \mathrm{~h}$ post-activation, respectively. Blastocysts were defined as embryos that contain a fluid-filled blastocoel and have at least 20 cells.

\subsection{IL17D Treatment}

Human IL17D protein (Cat no. CG96, Novoprotein, Fremont, CA, USA), which has 98\% homology to porcine IL17D in amino acid sequences, was added to the PZM-3 culture medium of porcine IVF and SCNT embryos at 1-cell stage (right after fertilization of IVF embryos or activation of SCNT embryos) or 4-cell stage ( $48 \mathrm{~h}$ post fertilization or activation of SCNT embryos). After culturing for $48 \mathrm{~h}$, the medium containing IL17D was replaced by PZM-3 medium. The experimental design and groups of IL17D treatment is shown in Table 1. 
Table 1. Experimental design of IL17D treatment of embryos.

\begin{tabular}{|c|c|c|c|c|}
\hline & $\begin{array}{l}\text { Types of Treated } \\
\text { Embryos }\end{array}$ & $\begin{array}{c}\text { Time Point of IL17D } \\
\text { Addition }\end{array}$ & Groups & Evaluation Indexes \\
\hline Experiment 1 & SCNT & 1-cell stage & $\mathrm{NC}, 5,25,50$ and $100 \mathrm{ng} / \mathrm{mL}$ & $\begin{array}{c}\text { Cleavage rate, blastocyst } \\
\text { rate }\end{array}$ \\
\hline Experiment 2 & IVF & 1-cell stage & $\mathrm{NC}, 50 \mathrm{ng} / \mathrm{mL}$ & $\begin{array}{l}\text { Cleavage rate, blastocyst } \\
\text { rate }\end{array}$ \\
\hline Experiment 3 & SCNT & 4-cell stage & $\mathrm{NC}, 50 \mathrm{ng} / \mathrm{mL}$ & $\begin{array}{c}\text { Cleavage rate, blastocyst } \\
\text { rate }\end{array}$ \\
\hline Experiment 4 & SCNT & 1-cell stage & $\mathrm{NC}, 50 \mathrm{ng} / \mathrm{mL}$ & $\begin{array}{l}\text { Total cell number, number } \\
\text { of apoptotic cells, } \\
\text { percentage of apoptosis } \\
\text { cells, apoptosis-related } \\
\text { gene expression levels at } \\
\text { blastocyst stage }\end{array}$ \\
\hline Experiment 4 & IVF & 1-cell stage & $\mathrm{NC}, 50 \mathrm{ng} / \mathrm{mL}$ & $\begin{array}{l}\text { Total cell number at } \\
\text { blastocyst stage }\end{array}$ \\
\hline Experiment 5 & SCNT & 1-cell stage & $\mathrm{NC}, 50 \mathrm{ng} / \mathrm{mL}$ & $\begin{array}{c}\text { Transcriptome sequencing } \\
\text { and qPCR validation at } \\
\text { 4-cell stage }\end{array}$ \\
\hline
\end{tabular}

\subsection{Transcriptome Sequencing}

Transcriptome sequencing was performed as previously described [50]. Twenty to thirty four-cell stage embryonic cells of the same treatment group were mixed as one sample and collected into a $1 \mathrm{~mL}$ tube containing $3 \mu \mathrm{L}$ of lysis buffer with RNase inhibitor. Complementary DNA (cDNA) was generated and amplified for sequencing based on smartseq2 method. After cDNA amplification and purification, the overall quality of the initial cell was performed with an Agilent 2100 Bioanalyzer. We determined the degradation of the sample according to the RNA integrity number by Agilent Bioanalyzer. The clustered library preparations were then sequenced on an Illumina Nova platform, and 150-bp paired-end reads were generated. Raw read data were the original RNA-Seq reads which used Trimmomatic to filter low-quality reads and trim the linker sequence [51]. Clean read data were then aligned to the susScr11 reference genome using STAR [52]. Reads aligned to genes are counted by cufflinks (v2.2.1). The fragments per kilobase of exon model per million mapped reads (FPKMs) are normalized using cuffnorm. Differentially expressed genes are calculated using cuffdiff [53]. Differentially expressed genes between two groups $(p<0.05)$ were filtered by $[\log 2$ FoldCharge $]>1$ and FPKM $>5$. Raw RNA-Seq data for 2-cell and 4-cell stage IVV Duroc embryos, SCNT Duroc embryos, and SCNT Laiwu embryos, were obtained from the Gene Expression Omnibus (GEO) datasets (accession no. GSE125706) [54].

\subsection{Quantitative Real-Time Polymerase Chain Reaction ( $q R T-P C R$ )}

Total RNAs were extracted from 4-cell stage embryos and blastocysts by using the Qiagen AllPrep DNA/RNA Micro Kit (Qiagen, Gaithersburg, MD, USA) according to the manufacturer's instructions. cDNA was generated by the PrimeScript RT reagent kit with gDNA Eraser (TAKARA, Shiga, Japan). The synthesized cDNA was used for qRT-PCR by PowerUp SYBR Green Master Mix (Thermo Fisher Scientific, CA, USA). qRT-PCR was performed on QuantStudio ${ }^{\mathrm{TM}} 7$ Flex Real-Time PCR System (Thermo Fisher Scientific) by following the parameters recommended by the manufacturer. The reactions were run and performed in triplicate as previously described [55]. GAPDH was used as the housekeeping gene, and the relative mRNA expression was calculated using the 2- $\Delta \Delta \mathrm{Ct}$ method. The primer sequences are shown in Table 2. The amplification efficiency of each pair of 
primers at different cDNA template concentrations was validated to be $>95 \%$ (Figure S1 and Table S1), following a previously reported method [56].

Table 2. Information of primers used for qRT-PCR.

\begin{tabular}{|c|c|c|c|}
\hline Gene & Primer Sequences $\left(5^{\prime}-3^{\prime}\right)$ & Product Size (bp) & Gene Accession Number \\
\hline BCL2 & $\begin{array}{c}\text { F: TCGCCCTGTGGATGACTGAGTAC } \\
\text { R: AGACAGCCAGGAGAAATCAAATAGAGG }\end{array}$ & 131 & XM_021099593 \\
\hline BCL2L1 & $\begin{array}{l}\text { F: TGAGCAGGTATTGAACGAACTCTTCC } \\
\text { R: CCATCCAAGTTGCGATCCGACTC }\end{array}$ & 143 & NM_214285 \\
\hline TP53 & $\begin{array}{l}\text { F: GCCCATCCTCACCATCATCACAC } \\
\text { R: GCACAAACACGCACCTCAAAGC }\end{array}$ & 81 & NM_213824 \\
\hline CYCS & $\begin{array}{l}\text { F: CGAGTGGTGGCTTGTCTGTTGAG } \\
\text { R: GGCACTGGGCACACTTCTGAAC }\end{array}$ & 101 & NM_001129970 \\
\hline BAX & $\begin{array}{l}\text { F: ATCGGCTGCTGGGCTGGATC } \\
\text { R: ATGGTGAGCGAGGCGGTGAG }\end{array}$ & 124 & XM_003127290 \\
\hline BCL2L11 & $\begin{array}{l}\text { F: TGCCAAGCCTTCAACCATTATCTCAG } \\
\text { R: GTCTCCAATACGCCGTAACTCCTG }\end{array}$ & 117 & NM_001160074 \\
\hline BAD & $\begin{array}{l}\text { F: CCGAGGAGGATGAAGGGACTGAG } \\
\text { R: AGGAACCCTGGAACTCGTCACTC }\end{array}$ & 138 & XM_021082883 \\
\hline FOS & $\begin{array}{l}\text { F: GGAGTCGTGAAGACCATGCC } \\
\text { R: TAGCTGGTCTGTCTCCGCTTG }\end{array}$ & 189 & NM_001123113 \\
\hline JUN & $\begin{array}{l}\text { F: AGGCGGAGAGGAAGCGTATGAG } \\
\text { R: CTGAGCATGTTGGCGGTGGAC }\end{array}$ & 145 & NM_213880 \\
\hline MAP3К8 & $\begin{array}{l}\text { F: CCAGTGAAGAGCCAGCAGTGTAC } \\
\text { R: GCAAGTCCTCCACGGTTCCATATC }\end{array}$ & 150 & XM_021064738 \\
\hline MYC & $\begin{array}{l}\text { F: TCAACGTCAGCTTCACCAACAGG } \\
\text { R: AAGTTCTCCTCCTCGTCGCAGTAG }\end{array}$ & 85 & NM_001005154 \\
\hline GADD45B & $\begin{array}{l}\text { F: TGAATTTGCTCTGTACCCAGGAACTC } \\
\text { R: GTAAGCCTCCCATCTCTCTTTCAGTG }\end{array}$ & 108 & XM_005654701 \\
\hline GAPDH & $\begin{array}{l}\text { F: TGACCCCTTCATTGACCTCC } \\
\text { R: CTCCGCCTTGACTGTGCC }\end{array}$ & 88 & XM_021091114 \\
\hline
\end{tabular}

2.9. Terminal Deoxynucleotidyl Transferase (TdT)-Mediated

2'-Deoxyuridine-5'-Triphosphate-Digoxigenin Nick-End Labeling (TUNEL) Assay

Blastocysts were analyzed by the TUNEL apoptosis detection kit (YEASEN, SH, China). The embryos were fixed in $4 \%$ paraformaldehyde and permeated for $30 \mathrm{~min}$ in $0.5 \%$ Triton $\mathrm{X}$-100. The embryos were incubated in TdT incubation buffer at $38^{\circ} \mathrm{C}$ for $1 \mathrm{~h}$. The nuclei were stained with Hoechst 33342 at room temperature for $5 \mathrm{~min}$. The stained embryos were placed on slides, and photos were taken under the microscope.

\subsection{Plasmid Construction}

The coding sequences (CDS) of porcine GADD45B gene (GenBank no. XM_005654701.2) was synthesized and inserted between the NheI and HindIII sites at the multiple cloning sites of the pcDNA3.1(+)-EGFP vector to generate the pcDNA3.1-GADD45B-EGFP vector.

\subsection{Microinjection}

Microinjection of the porcine $G A D D 45 B$ expression plasmid into cloned pig embryos was performed using a micropipette driven by a Piezo (Eppendorf). Ten picoliter of plasmids or water was injected into the cytoplasm of each embryo after activation of SCNT embryos. After microinjection, the embryos were transferred to PZM-3 and cultured in an incubator at $38.5^{\circ} \mathrm{C}$ and $5 \% \mathrm{CO}_{2}$.

\subsection{Statistical Analysis}

SPSS software version 20 was used for statistical analysis. A Chi-square test was performed to determine differences in cleavage rate, blastocyst rate, and percentage of 
apoptosis cells. One-way ANOVA was performed to evaluate differences in gene expression level and total cell number of blastocysts.

\section{Results}

3.1. IL17D Expression Is Abnormal in Cloned Pig Embryos Compared to That in In Vivo-Fertilization-Derived Pig Embryos

Analysis of a published transcriptome sequencing data set showed that the expression of IL17D mRNA is up-regulated by approximately eight folds in in vivo fertilizationderived (IVV) porcine embryos while it is unchanged in cloned porcine embryos during the 2-cell to 4-cell stage (Figure 1). This suggests that up-regulation of IL17D expression during early stage is required for normal porcine embryo development and the expression of IL17D in cloned pig embryos is abnormal.

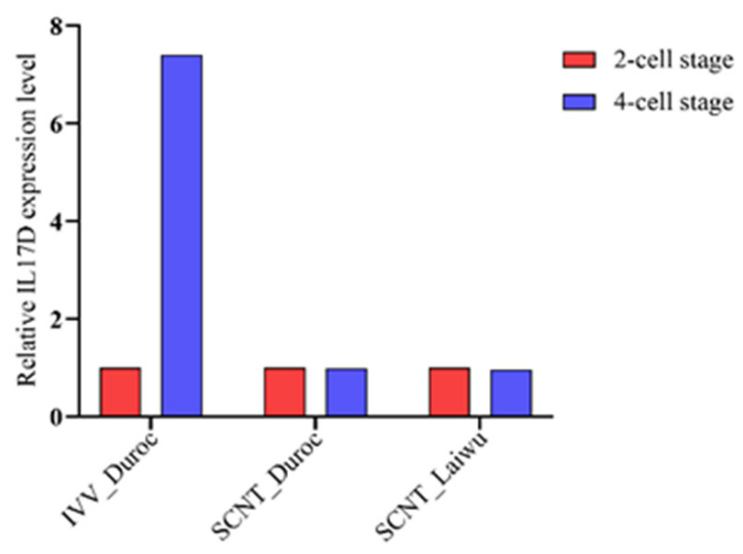

Figure 1. Relative IL17D mRNA expression level in 2-cell and 4-cell stage IVV Duroc embryos, SCNT Duroc embryos, and SCNT Laiwu embryos.

\subsection{IL17D Treatment Improved the Developmental Competence of Porcine SCNT and \\ IVF Embryos}

The activated cloned embryos at the 1-cell stage were treated with 5, 25, 50 and $100 \mathrm{ng} / \mathrm{mL}$ IL17D for $48 \mathrm{~h}$ to examine the effects of IL17D on porcine SCNT embryo development. Treatment with $50 \mathrm{ng} / \mathrm{mL}$ IL17D significantly enhanced the blastocyst rates of porcine SCNT embryos (Table 3). Treatment with 25 and $100 \mathrm{ng} / \mathrm{mL}$ IL17D did not significantly improve but tented to improve the blastocyst rate of porcine SCNT embryos (Table 3). The addition of $50 \mathrm{ng} / \mathrm{mL}$ IL17D at 1-cell stage for $48 \mathrm{~h}$ also significantly enhanced the blastocyst rate of the treated porcine IVF embryos (Table 4). However, treatment with porcine SCNT embryos with $50 \mathrm{ng} / \mathrm{mL}$ IL17D at 4-cell stage for $48 \mathrm{~h}$ did not significantly affect the developmental efficiency (Table 5).

Table 3. Developmental efficiency of SCNT embryos treated with IL17D at 1-cell stage for $48 \mathrm{~h}$.

\begin{tabular}{ccccc}
\hline Groups & $\begin{array}{c}\text { No. of } \\
\text { Repetition }\end{array}$ & $\begin{array}{c}\text { No. of Cultured } \\
\text { SCNT Embryos }\end{array}$ & $\begin{array}{c}\text { No. of Cleaved } \\
\text { Embryos (\%) }\end{array}$ & $\begin{array}{c}\text { No. of Blastocysts } \\
\mathbf{( \% )}\end{array}$ \\
\hline $\begin{array}{l}\mathrm{NC} \\
5 \mathrm{ng} / \mathrm{mL}\end{array}$ & 4 & 160 & $127\left(79.12 \pm 5.21^{\mathrm{a}}\right)$ & $25\left(15.48 \pm 4.9^{\mathrm{a}}\right)$ \\
$\begin{array}{l}\mathrm{IL} 17 \mathrm{D} \\
25 \mathrm{ng} / \mathrm{mL}\end{array}$ & 3 & 105 & $78\left(74.29 \pm 2.86^{\mathrm{a}}\right)$ & $18\left(17.14 \pm 5.71^{\mathrm{ab}}\right)$ \\
$\begin{array}{l}\text { IL17D } \\
50 \mathrm{ng} / \mathrm{mL} \\
\text { IL17D }\end{array}$ & 3 & 107 & $76\left(72.38 \pm 7.19^{\mathrm{a}}\right)$ & $21\left(19.6 \pm 2.54^{\mathrm{ab}}\right)$ \\
$\begin{array}{c}100 \mathrm{ng} / \mathrm{mL} \\
\text { IL17D }\end{array}$ & 4 & 166 & $131\left(81.62 \pm 6.99^{\mathrm{a}}\right)$ & $46\left(27.59 \pm 3.09^{\mathrm{c}}\right)$ \\
\hline
\end{tabular}

$\mathrm{NC}$, negative control. Values in the same column labeled with a same superscript have no significant difference with each other, labeled with a different superscript differ at $p<0.05$. 
Table 4. Developmental efficiency of IVF embryos treated with IL17D at 1-cell stage for $48 \mathrm{~h}$.

\begin{tabular}{ccccc}
\hline Groups & $\begin{array}{c}\text { No. of } \\
\text { Repetition }\end{array}$ & $\begin{array}{c}\text { No. of Cultured } \\
\text { SCNT Embryos }\end{array}$ & $\begin{array}{c}\text { No. of Cleaved } \\
\text { Embryos (\%) }\end{array}$ & $\begin{array}{c}\text { No. of Blastocysts } \\
\text { (\%) }\end{array}$ \\
\hline $\begin{array}{c}\text { NC } \\
50 \mathrm{ng} / \mathrm{mL}\end{array}$ & 6 & 298 & $211\left(69.64 \pm 8.76^{\mathrm{a}}\right)$ & $45\left(14.97 \pm 4.14^{\mathrm{a}}\right)$ \\
IL17D & 6 & 289 & $210\left(71.66 \pm 8.32^{\mathrm{a}}\right)$ & $67\left(23.54 \pm 3.34^{\mathrm{b}}\right)$ \\
\hline
\end{tabular}

$\mathrm{NC}$, negative control. Values in the same column labeled with a same superscript have no significant difference with each other, labeled with a different superscript differ at $p<0.05$.

Table 5. Developmental efficiency of SCNT embryos treated with IL17D at 4-cell stage for $48 \mathrm{~h}$.

\begin{tabular}{ccccc}
\hline Groups & $\begin{array}{c}\text { No. of } \\
\text { Repetition }\end{array}$ & $\begin{array}{c}\text { No. of Cultured } \\
\text { SCNT Embryos }\end{array}$ & $\begin{array}{c}\text { No. of Cleaved } \\
\text { Embryos (\%) }\end{array}$ & $\begin{array}{c}\text { No. of Blastocysts } \\
\text { (\%) }\end{array}$ \\
\hline $\begin{array}{c}\mathrm{NC} \\
50 \mathrm{ng} / \mathrm{mL}\end{array}$ & 3 & 122 & $91\left(74.57 \pm 1.8^{\mathrm{a}}\right)$ & $15\left(12.28 \pm 2.32^{\mathrm{a}}\right)$ \\
$\mathrm{IL} 17 \mathrm{D}$ & 3 & 117 & $88\left(75.21 \pm 2.96^{\mathrm{a}}\right)$ & $14\left(11.97 \pm 1.48^{\mathrm{a}}\right)$ \\
\hline
\end{tabular}

$\overline{\mathrm{NC}}$, negative control. Values in the same column labeled with a same superscript means they are not statistically different.

\subsection{IL17D Treatment Inhibited the Apoptosis of Porcine SCNT and IVF Embryos at Blastocyst Stage}

Treatment with $50 \mathrm{ng} / \mathrm{mL}$ IL17D at 1-cell stage for $48 \mathrm{~h}$ also significantly increased the total cell number of porcine SCNT and IVF embryos at the blastocyst stage (Figure 2A,C). The number and proportion of apoptotic cells at the blastocyst stage significantly decreased in porcine SCNT embryos treated with IL17D (Figure 2B,D,E). At the blastocyst stage of IL17D-treated porcine SCNT embryos, the mRNA expression of the pro-apoptotic gene $B C L 2 L 11$ was down-regulated and the transcription of the anti-apoptotic gene BCL2 was up-regulated. The mRNA abundance of four other tested apoptosis-related genes was not significantly changed (Figure 2F). These results indicated that IL17D treatment inhibited apoptosis in porcine SCNT embryos.

\subsection{IL17D Treatment Increased the Expression of Global Genes in Porcine SCNT Embryos at 4-Cell Stage}

We observed that porcine SCNT embryos treated with $50 \mathrm{ng} / \mathrm{mL}$ IL17D at 1-cell stage for $48 \mathrm{~h}$ exhibited higher developmental rate than the control group at 4-cell stage (Figure 3A). This observation, together with the result shown in Table 5, suggested that the added IL17D in the embryo culture medium exerted or started to exert its effects before the 4-cell stage of porcine SCNT embryos. Therefore, 4-cell stage SCNT-IL17D and SCNT-NC embryos were collected for transcriptome sequencing to compare their differences in gene expression patterns. The PCA results showed that three samples in the SCNT-IL17D (IL) group were separated from the three other samples in the SCNT-NC (NC) group (Figure 3B). This finding implied that the two groups of embryos had different gene expression patterns. The mRNA expression level of transcriptome sequencing-detected genome-wide genes was significantly increased in the IL group compared with that in the NC group (Figure 3C). The analysis of differentially expressed genes (DEGs) showed that in IL embryos, the number of up-regulated genes (175) was higher than the number of down-regulated genes (30) (Figure 3D). Hence, IL17D treatment up-regulated the expression of global genes in porcine SCNT embryos at the 4-cell stage. To confirm the transcriptome sequencing data, we randomly selected eight genes including FOS, JUN, BAX, BAD, MAP3K8, MYC, $B C L 2 L 11$, and GADD45B for qRT-PCR verification. The mRNA expression levels of the eight genes examined by transcriptome sequencing matched with those measured by qRT-PCR (Figure 3E,F). 

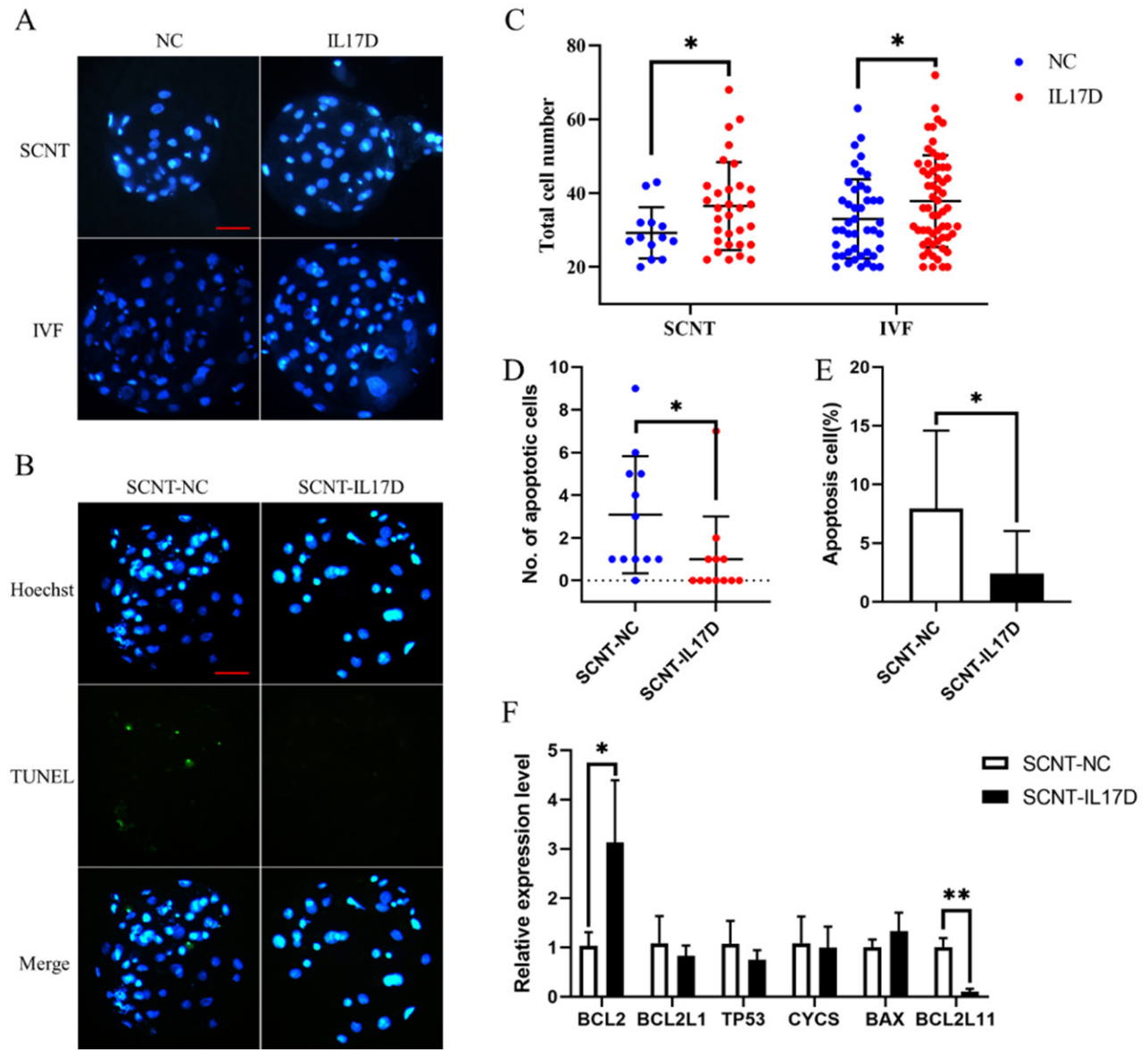

Figure 2. Effect of IL17D treatment on apoptosis of SCNT and IVF embryos. (A) Nuclear staining of SCNT-NC, SCNT-IL17D, IVF-NC and IVF-IL17D embryos at blastocyst stage by Hoechst33342 (blue). Bar $=100 \mu \mathrm{m}$. (B) TUNEL assay of SCNT-NC, SCNT-IL17D embryos at blastocyst stage. Bar $=100 \mu \mathrm{m}$. (C) Total cell number of SCNT-NC, SCNT-IL17D, IVF-NC and IVF-IL17D embryos at blastocyst stage. (D) Number and (E) proportion of apoptotic cells of SCNT-NC, SCNT-IL17D embryos at blastocyst stage. (F) The mRNA expression level of apoptosis-related genes of SCNT-NC and SCNT-IL17D embryos at blastocyst stage. Data were obtained from three independent replicates. Values were presented as mean \pm SEM. ${ }^{*}$ and ${ }^{* *}$ means $p<0.05$ and $p<0.01$, respectively.

\subsection{IL17D Treatment Improved Porcine SCNT Embryo Development by Regulating Apoptosis-Related Pathways}

Among the top 10 significantly enriched KEGG pathways for DEGs between IL and NC groups, three pathways including apoptosis pathway, MAPK signaling pathway, and NF-kappa B signaling pathway are involved in the IL17 signaling pathway (Figure 4A) [57]. The three IL17-related pathways are also relevant to apoptosis. The transcription levels of most DEGs enriched in the three apoptosis-associated pathways, including pro-apoptotic and anti-apoptotic/pro-survival genes, were up-regulated in IL group compared with those in NC group (Figure 4B) [58]. These results suggested that IL17D signal through the IL17 pathway to act on apoptosis-related genes to enhance cloned porcine embryo development. 

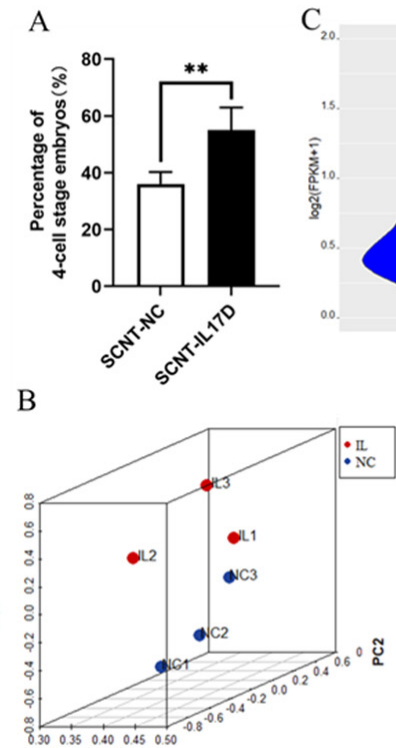

PC1

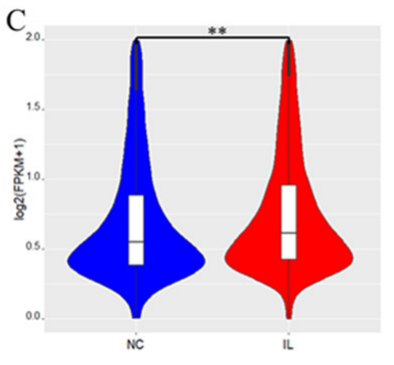

$\mathrm{D}$

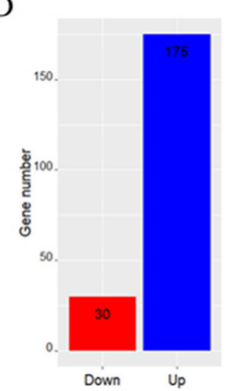

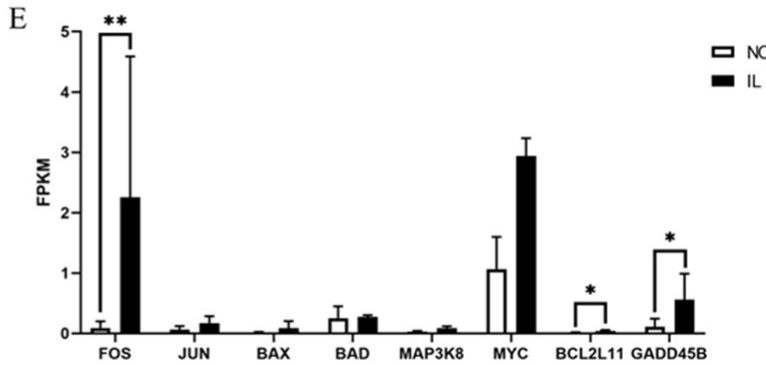

F

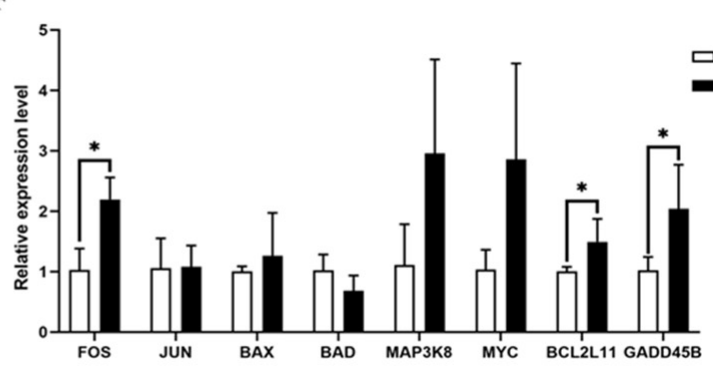

Figure 3. Transcriptome sequencing of SCNT-IL17D (IL) and SCNT-NC (NC) embryos at 4-cell stage. (A) Comparison of the percentage of embryos developing to 4-cell stage between SCNT-IL17D and SCNT-NC groups. (B) Principal component analysis (PCA) plot for six samples from IL and NC groups at 4-cell stage. Each sample was a mixture of 20 to 30 embryos. (C) Violin plot of mRNA levels of 6296 transcriptome sequencing-detected genes (with the sum of individual gene's FPKM value >1) of IL and NC embryos at 4-cell stage. (D) Bar plot of differentially expressed genes (IL vs. NC) between IL and NC groups at 4-cell stage. (E) Transcriptome sequencing-detected mRNA expression levels of eight randomly selected genes in NC and IL group. (F) qRT-PCR -measured relative mRNA expression levels of the same eight genes in SCNT-NC and SCNT-IL17D embryos at 4-cell stage. Data were obtained from three independent replicates. Values were presented as mean \pm SEM. ${ }^{*}$ and ${ }^{* *}$ means $p<0.05$ and $p<0.01$, respectively.
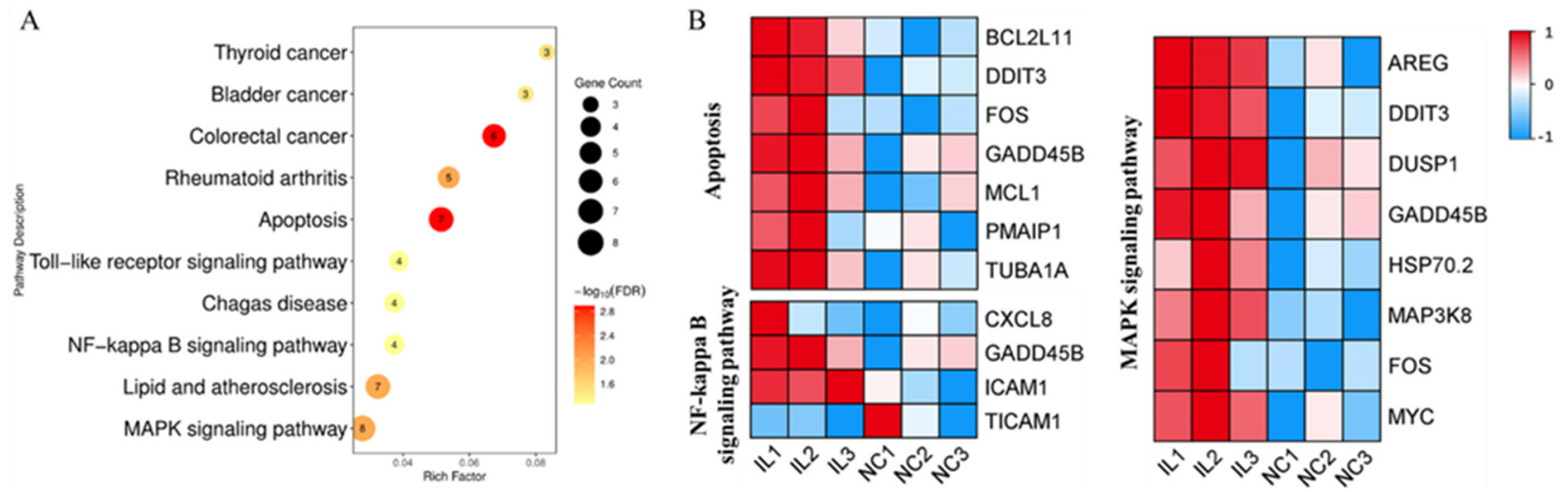

Figure 4. Analysis of transcriptome data of 4-cell stage SCNT-IL17D and SCNT-NC embryos. (A) Kyoto Encyclopedia of Genes and Genomes (KEGG) pathway analysis of DEGs between 4-cell stage SCNT-IL17D and SCNT-NC embryos. (B) Heatmap of DEGs participated in three apoptosis-related pathways.

3.6. The Effects of IL17D on Improving Porcine SCNT Embryo Development Might Be Related to the Up-Regulation of GADD45B Expression

The above results suggested that IL17D enhanced pig SCNT embryo development by inhibiting apoptosis and promoting EGA. Among the genes whose expression was up-regulated at 4-cell stage in IL17D-treated pig SCNT embryos, GADD45B was noticeable because it not only has anti-apoptotic functions [59,60], but also plays important roles in EGA [61]. To examine whether the effects of IL17D on enhancing pig SCNT embryo development is related to the upregulation of $G A D D 45 B$ expression, we constructed a porcine $G A D D 45 B$ expression plasmid (Figure $5 \mathrm{~A}$ ) and injected it into cloned pig embryos. 
Expression of the EGFP marker gene that was linked to the porcine GADD45B gene was observed at 2-cell stage of injected pig SCNT embryos (Figure $5 B$ ). This suggested that $G A D D 45 B$ was overexpressed in injected pig SCNT embryos. Injection of GADD45B expression plasmid showed no effect on the total cell number at blastocyst stage of cloned pig embryos (Figure 5C). However, injection of $100 \mathrm{ng} / \mu \mathrm{L}$ of GADD45B expression plasmid increased the blastocyst rate of cloned pig embryos and injection of $50 \mathrm{ng} / \mu \mathrm{L}$ and $10 \mathrm{ng} / \mu \mathrm{L}$ of GADD $45 B$ expression plasmid tended to improve the blastocyst rate of cloned pig embryos (Table 6). This suggested that IL17D improved porcine SCNT embryo development probably by up-regulating GADD45B expression.

A

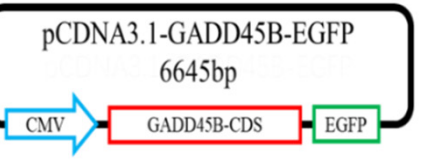

B

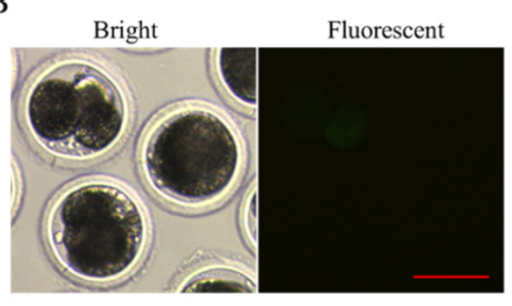

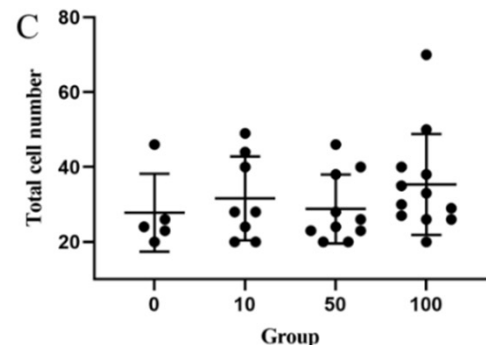

Figure 5. Overexpression of GADD45B in cloned pig embryos. (A) Map of the porcine GADD45B expression plasmid. (B) Expression of EGFP marker gene at 2-cell stage of injected cloned pig embryos. Bar $=100 \mu \mathrm{m}$. (C) Total cell number at blastocyst stage of SCNT embryos injected with GADD45B expression plasmid.

Table 6. Developmental efficiency of SCNT embryos injected with GADD45B expression plasmid.

\begin{tabular}{ccccc}
\hline Groups & $\begin{array}{c}\text { No. of } \\
\text { Repetition }\end{array}$ & $\begin{array}{c}\text { No. of Cultured } \\
\text { SCNT Embryos }\end{array}$ & $\begin{array}{c}\text { No. of Cleaved } \\
\text { Embryos (\%) }\end{array}$ & $\begin{array}{c}\text { No. of Blastocysts } \\
\text { (\%) }\end{array}$ \\
\hline $\mathrm{NC}$ & 3 & 113 & $88\left(77.9 \pm 5.94^{\mathrm{a}}\right)$ & $5\left(4.41 \pm 1.48^{\mathrm{a}}\right)$ \\
$10 \mathrm{ng} / \mu \mathrm{L}$ & 3 & 113 & $77\left(68.14 \pm 0.49^{\mathrm{a}}\right)$ & $8\left(7.09 \pm 1.58^{\mathrm{a}}\right)$ \\
$50 \mathrm{ng} / \mu \mathrm{L}$ & 3 & 111 & $78\left(69.61 \pm 4.45^{\mathrm{a}}\right)$ & $10\left(8.89 \pm 5.49^{\mathrm{a}}\right)$ \\
$100 \mathrm{ng} / \mu \mathrm{L}$ & 3 & 112 & $82\left(73.87 \pm 7.8^{\mathrm{a}}\right)$ & $12\left(10.81 \pm 2.7^{\mathrm{b}}\right)$ \\
\hline
\end{tabular}

Values in the same column labeled with a same superscript have no significant difference with each other, labeled with a different superscript differ at $p<0.05$.

\section{Discussion}

IL17D enhanced porcine SCNT embryo development by inhibiting apoptosis. The functions of IL17D observed in porcine SCNT embryos are consistent with those reported in mouse IVF embryos [46]. Our transcriptome data showed that the expression levels of pro-apoptotic DEGs such as BCL2L11 [62], PMAIP1 [63], and DDIT3 [64] were up-regulated with anti-apoptotic DEGs such as GADD45B [60], MCL1 [65], and DUSP1 [66], in SCNTIL17D embryos compared with those in SCNT-NC embryos. However, the ratio of the expression level of pro-apoptotic genes to that of anti-apoptotic genes might be lower in SCNT-IL17D embryos than in SCNT-NC embryos. This phenomenon might result in the overall anti-apoptotic effect in IL17D-treated SCNT embryos, which is supported by the data of this study.

In early mouse embryos, transcription of IL17D is positively associated with the expression of its promoter-associated noncoding RNA (pancil17d), which is oppositely transcribed from the bidirectional IL17D promoter and is indispensable for EGA of mouse embryos [46]. This suggested that IL17D is involved in EGA. SCNT embryos are associated with defects of embryonic genome activation (EGA) [54,67]. IL17D also promoted EGA in treated porcine SCNT embryos because it increased the expression of global genes at 4-cell stage, which is the major EGA stage for porcine embryos $[68,69]$. The promotion of EGA in porcine SCNT embryos by IL17D might be related to the up-regulation of the expression of GADD45B, which is functional in inhibiting apoptosis and promoting EGA [59-61]. More 
importantly, overexpression of $G A D D 45 B$ enhanced the developmental ability of cloned pig embryos.

IL17D transcription was naturally increased by about eight folds in porcine IVV embryos during 2-cell to 4-cell stage, suggesting that the up-regulation of IL17D before the 4-cell stage is required for normal porcine embryo development. This finding is consistent with our observation that the developmental ability of porcine SCNT embryos was improved by supplementation of IL17D at 1-cell stage but not at 4-cell stage. Nevertheless, the addition of IL17D at the 4-cell stage of mouse IVF embryos rescued the developmental failure induced by the suppression of IL17D expression. The difference in the action time point of IL17D in porcine SCNT embryos and mouse IVF embryos might be related to their differences in species and type of embryos.

We also tried to knock down IL17D expression by RNA interference to examine its effects on cloned porcine embryo development (data not shown). However, only one siRNA with high specificity for targeting porcine IL17D mRNA was predicted by professional siRNA designing software due to the high homology of the IL17D gene to a gene called EEF1A lysine methyltransferase 1 in the pig genome. This potential IL17D-targeting siRNA could not decrease the porcine IL17D transcript level in transfected porcine cells and injected porcine SCNT embryos. Therefore, in the future, other strategies, such as IL17D gene knockout, should be employed to investigate the effects of inhibiting IL17D expression on porcine embryo development. In addition, future studies should test whether IL17D also participates in regulating the development of the SCNT embryos of other species, and whether IL17D can also improve the in vivo full-term developmental competence of cloned embryos.

\section{Conclusions}

In summary, IL17D improved the developmental competence of cloned porcine embryos by suppressing apoptosis and promoting EGA, which probably was related to the up-regulation of $G A D D 45 B$ expression. This study not only elucidated the functions of IL17D in early development of porcine SCNT embryos but also provided a new way to increase the developmental efficiency of cloned porcine embryos.

Supplementary Materials: The following are available online at https:/ /www.mdpi.com/article/ 10.3390/ani11113062/s1, Figure S1: Validation of amplification efficiency of each pair of primers, Table S1: Primer-specific amplification efficiencies.

Author Contributions: Conceptualization, X.W., H.Z. and Z.L.; methodology, H.Z., X.W., J.S., R.Z. and Q.S.; software, J.L. and N.Z.; validation, E.Z., Z.X. and S.H.; formal analysis, T.G., J.Y. and H.Y.; investigation, L.H.; resources, J.S., R.Z. and Q.S.; writing—original draft preparation, X.W.; writing-review and editing, X.W., H.Z. and Z.L.; project administration, Z.L., Z.W. and G.C.; funding acquisition, Z.W. and G.C. All authors have read and agreed to the published version of the manuscript.

Funding: This work was supported by a grant from the National Natural Science Foundation of China (grant number: 31772554) and two grants from the Department of Science and Technology of Guangdong Province, China (grant numbers: 2019B1515210027, and 2019BT02N630).

Institutional Review Board Statement: The study was conducted according to the guidelines of the Declaration of Helsinki, and approved by the Institutional Animal Care and Use Committee of South China Agricultural University (Approval No.2018-P006).

Data Availability Statement: The original data generated for this study are included in the article, further inquiries can be directed to the corresponding author.

Conflicts of Interest: The authors declare no conflict of interest.

\section{Abbreviations}

BAD, BCL2 associated agonist of cell death; BAX, BCL2 associated X; BCL2, B cell leukemia/lymphoma 2; BCL2L11, BCL2 like 11; BSA, bovine serum albumin; cDNA, complementary DNA; CDS, coding 
sequences; COCs, cumulus-oocyte complexes; CSF2, colony stimulating factor 2; DEGs, differentially expressed genes; DMEM, Dulbecco's modified eagle medium; DPBS, Dulbecco's phosphate-buffered saline; EGA, embryonic genome activation; EGFP, enhanced green fluorescent protein; FBS, fetal bovine serum; FOS, Fos proto-oncogene, AP-1 transcription factor subunit; FPKMs, fragments per kilobase of exon model per million mapped reads; GADD45B, growth arrest and DNA damage inducible beta; IGF1, insulin like growth factor 1; IL17D, interleukin 17D; IVF, in vitro fertilization; JUN, Jun proto-oncogene, AP-1 transcription factor subunit; MAPK, mitogen-activated protein kinase; MAP3K8, mitogen-activated protein kinase kinase kinase 8; mTBM, modified Tris-buffered medium; MYC, MYC proto-oncogene, bHLH transcription factor; PZM-3, porcine zygote medium 3; qRT-PCR, Quantitative real-time polymerase chain reaction; TUNEL, terminal deoxynucleotidyl transferase (TdT)-mediated 2'-deoxyuridine-5'-triphosphate-digoxigenin nick-end labeling; SCNT, somatic cell nuclear transfer.

\section{References}

1. Li, Z.; He, X.; Chen, L.; Shi, J.; Rong, Z.; Xu, W.; Liu, D.; Wu, Z. Bone marrow mesenchymal stem cells are an attractive donor cell type for production of cloned pigs as well as genetically modified cloned pigs by somatic cell nuclear transfer. Cell. Reprogram. 2013, 15, 459-470. [CrossRef]

2. Shi, J.; Tan, B.; Luo, L.; Li, Z.; Hong, L.; Yang, J.; Cai, G.; Zheng, E.; Wu, Z.; Gu, T. Assessment of the growth and reproductive performance of cloned pietrain boars. Animals 2020, 10, 2053. [CrossRef]

3. Zhang, X.; Li, Z.; Yang, H.; Liu, D.; Cai, G.; Li, G.; Mo, J.; Wang, D.; Zhong, C.; Wang, H. Novel transgenic pigs with enhanced growth and reduced environmental impact. eLife 2018, 7, e34286. [CrossRef] [PubMed]

4. Su, F.; Wang, Y.; Liu, G.; Ru, K.; Liu, X.; Yu, Y.; Liu, J.; Wu, Y.; Quan, F.; Guo, Z.; et al. Generation of transgenic cattle expressing human $\beta$-defensin 3 as an approach to reducing susceptibility to Mycobacterium bovis infection. FEBS J. 2016, 283, 776-790. [CrossRef] [PubMed]

5. Zhang, Y.; Wang, Y.; Yulin, B.; Tang, B.; Wang, M.; Zhang, C.; Zhang, W.; Jin, J.; Li, T.; Zhao, R. CRISPR/Cas9-mediated sheep MSTN gene knockout and promote sSMSCs differentiation. J. Cell. Biochem. 2018, 120, 1794-1806. [CrossRef] [PubMed]

6. Liu, Y.; Li, J.; Vendahl, L.P.; Schmidt, M.; Larsen, K.; Callesen, H. In Vitro manipulation techniques of porcine embryos: A meta-analysis related to transfers, pregnancies and piglets. Reprod. Fertil. Dev. 2014, 27, 429. [CrossRef]

7. Skrzyszowska, M.; Samiec, M. Generating cloned goats by somatic cell nuclear transfer-molecular determinants and application to transgenics and biomedicine. Int. J. Mol. Sci. 2021, 22, 7490. [CrossRef]

8. Czernik, M.; Anzalone, D.A.; Palazzese, L.; Oikawa, M.; Loi, P. Somatic cell nuclear transfer: Failures, successes and the challenges ahead. Int. J. Dev. Biol. 2019, 63, 123-130. [CrossRef] [PubMed]

9. Keefer, C.L. Lessons learned from nuclear transfer (cloning). Theriogenology 2008, 69, 48-54. [CrossRef]

10. Samiec, M.; Skrzyszowska, M. Preimplantation developmental capability of cloned pig embryos derived from different types of nuclear donor somatic cells. Ann. Anim. Sci. 2010, 10, 385-398.

11. Em, S.; Shah, F.; Kataria, M.; Yadav, P.S. A comparative study on expression profile of developmentally important genes during pre-implantation stages in buffalo hand-made cloned embryos derived from adult fibroblasts and amniotic fluid derived stem cells. Cytotechnology 2016, 68, 1447-1461. [CrossRef] [PubMed]

12. Samiec, M.; Skrzyszowska, M. Assessment of In Vitro developmental capacity of porcine nuclear-transferred embryos reconstituted with rumulus oophorus cells undergoing vital diagnostics for apoptosis detection / ocena zdolności rozwojowych In Vitro klonalnych zarodków świni rekonsty. Ann. Anim. Sci. 2013, 13, 513-529. [CrossRef]

13. Lee, J.; Lee, Y.; Lee, G.S.; Lee, S.T.; Lee, E. Comparative study of the developmental competence of cloned pig embryos derived from spermatogonial stem cells and fetal fibroblasts. Reprod. Domest. Anim. 2019, 54, 1258-1264. [CrossRef] [PubMed]

14. Wiater, J.; Samiec, M.; Skrzyszowska, M.; Lipinski, D. Trichostatin A-assisted epigenomic modulation affects the expression profiles of not only recombinant human alpha 1,2-fucosyltransferase and alpha-galactosidase A enzymes but also galalpha1-> 3Gal epitopes in porcine Bi-transgenic adult cutaneous fibroblast cells. Int. J. Mol. Sci. 2021, 22, 1386.

15. Gupta, M.K.; Heo, Y.T.; Kim, D.K.; Lee, H.T.; Uhm, S.J. 5-Azacytidine improves the meiotic maturation and subsequent In Vitro development of pig oocytes. Anim. Reprod. Sci. 2019, 208, 106118. [CrossRef] [PubMed]

16. Wang, H.; Cui, W.; Meng, C.; Zhang, J.; Li, Y.; Qian, Y.; Xing, G.; Zhao, D.; Cao, S. MC1568 enhances histone acetylation during oocyte meiosis and improves development of somatic cell nuclear transfer embryos in pig. Cell. Reprogram. 2018, 20, 55-65. [CrossRef]

17. Akagi, S.; Tamura, S.; Matsukawa, K. Timing of the first cleavage and In Vitro developmental potential of bovine somatic cell nuclear transfer embryos activated by different protocols. Cell. Reprogram. 2020, 22, 36-42. [CrossRef]

18. Samiec, M.; Skrzyszowska, M. The use of different methods of oocyte activation for generation of porcine fibroblast cell nuclear-transferred embryos. Ann. Anim. Sci. 2010, 10, 399-411. 
19. Ongaratto, F.L.; Rodriguez-Villamil, P.; Bertolini, M.; Carlson, D.F. Influence of oocyte selection, activation with a zinc chelator and inhibition of histone deacetylases on cloned porcine embryo and chemically activated oocytes development. Zygote 2020, 28, 286-290. [CrossRef]

20. Samiec, M.; Skrzyszowska, M.; Lipinski, D. Pseudophysiological transcomplementary activation of reconstructed oocytes as a highly efficient method used for producing nuclear-transferred pig embryos originating from transgenic foetal fibroblast cells Pol. J. Vet. Sci. 2012, 15, 509-516. [CrossRef]

21. Agrawal, H.; Selokar, N.L.; Saini, M.; Singh, M.K.; Chauhan, M.S.; Palta, P.; Singla, S.K.; Manik, R.S. m-carboxycinnamic acid bishydroxamide improves developmental competence, reduces apoptosis and alters epigenetic status and gene expression pattern in cloned buffalo (Bubalus bubalis) embryos. Reprod. Domest. Anim. 2018, 53, 986-996. [CrossRef]

22. Jeong, P.S.; Sim, B.W.; Park, S.H.; Kim, M.J.; Kang, H.G.; Nanjidsuren, T.; Lee, S.; Song, B.S.; Koo, D.B.; Kim, S.U. Chaetocin improves pig cloning efficiency by enhancing epigenetic reprogramming and autophagic activity. Int. J. Mol. Sci. 2020, 21, 4836. [CrossRef]

23. Samiec, M.; Romanek, J.; Lipiński, D.; Opiela, J. Expression of pluripotency-related genes is highly dependent on trichostatin Aassisted epigenomic modulation of porcine mesenchymal stem cells analysed for apoptosis and subsequently used for generating cloned embryos. Anim. Sci. J. 2019, 90, 1127-1141. [CrossRef] [PubMed]

24. Magalhaes, L.C.; Cortez, J.V.; Bhat, M.H.; Sampaio, A.; Freitas, J.; Duarte, J.; Melo, L.M.; Freitas, V. In Vitro development and mitochondrial gene expression in brown brocket deer (Mazama gouazoubira) embryos obtained by interspecific somatic cell nuclear transfer. Cell. Reprogram. 2020, 22, 208-216. [CrossRef] [PubMed]

25. Samiec, M. The role of mitochondrial genome (mtDNA) in somatic and embryo cloning of mammals. A review. J. Anim. Feed Sci. 2005, 14, 213-233. [CrossRef]

26. Srirattana, K.; Matsukawa, K.; Akagi, S.; Tasai, M.; Tagami, T.; Nirasawa, K.; Nagai, T.; Kanai, Y.; Parnpai, R.; Takeda, K. Constant transmission of mitochondrial DNA in intergeneric cloned embryos reconstructed from swamp buffalo fibroblasts and bovine ooplasm. Anim. Sci. J. 2011, 82, 236-243. [CrossRef]

27. Samiec, M. The effect of mitochondrial genome on architectural remodeling and epigenetic reprogramming of donor cell nuclei in mammalian nuclear transfer-derived embryos. J. Anim. Feed Sci. 2005, 14, 393-422. [CrossRef]

28. Xu, L.; Mesalam, A.; Lee, K.L.; Song, S.H.; Khan, I.; Chowdhury, M.; Lv, W.; Kong, I.K. Improves the In Vitro developmental competence and reprogramming efficiency of cloned bovine embryos by additional complimentary cytoplasm. Cell. Reprogram. 2019, 21, 51-60. [CrossRef]

29. Samiec, M.; Skrzyszowska, M. Extranuclear inheritance of mitochondrial genome and epigenetic reprogrammability of chromosomal telomeres in somatic cell cloning of mammals. Int. J. Mol. Sci. 2021, 22, 3099. [CrossRef] [PubMed]

30. Song, S.H.; Oh, S.H.; Xu, L.; Lee, K.L.; Hwang, J.Y.; Joo, M.D.; Kong, I.K. Effect of additional cytoplasm of cloned embryo on In Vitro developmental competence and reprogramming efficiency in mice. Cell. Reprogram. 2020, 22, 236-243. [CrossRef]

31. Konno, S.; Wakayama, S.; Ito, D.; Kazama, K.; Hirose, N.; Ooga, M.; Wakayama, T. Removal of remodeling/reprogramming factors from oocytes and the impact on the full-term development of cloned embryos. Development 2020, 147, dev.190777. [CrossRef] [PubMed]

32. Samiec, M.; Skrzyszowska, M. Can reprogramming of overall epigenetic memory and specific parental genomic imprinting memory within donor cell-inherited nuclear genome be a major hindrance for the somatic cell cloning of mammals?-A review. Ann. Anim. Sci. 2018, 18, 623-638. [CrossRef]

33. Zhou, C.; Zhang, J.; Zhang, M.; Wang, D.; Ma, Y.; Wang, Y.; Wang, Y.; Huang, Y.; Zhang, Y. Transcriptional memory inherited from donor cells is a developmental defect of bovine cloned embryos. FASEB J. 2020, 34, 1637-1651. [CrossRef] [PubMed]

34. Hao, Y. Apoptosis and In Vitro development of preimplantation porcine embryos derived In Vitro or by nuclear transfer. Biol. Reprod. 2003, 69, 501. [CrossRef]

35. Kamjoo, M.; Brison, D.R.; Kimber, S.J. Apoptosis in the preimplantation mouse embryo: Effect of strain difference and In Vitro culture. Mol. Reprod. Dev. 2010, 61, 67-77. [CrossRef]

36. Bohrer, R.C.; Che, L.; Goncalves, P.; Duggavathi, R.; Bordignon, V. Phosphorylated histone H2A.x in porcine embryos produced by IVF and somatic cell nuclear transfer. Reproduction 2013, 146, 325-333. [CrossRef]

37. Chen, H.; Zhang, L.; Guo, Z.; Wang, Y.; He, R.; Qin, Y.; Quan, F.; Zhang, Y. Improving the development of early bovine somatic-cell nuclear transfer embryos by treating adult donor cells with vitamin C. Mol. Reprod. Dev. 2016, 82, 867-879. [CrossRef] [PubMed]

38. Wang, X.; Falcone, T.; Attaran, M.; Goldberg, J.M.; Agarwal, A.; Sharma, R.K. Vitamin C and vitamin E supplementation reduce oxidative stress-induced embryo toxicity and improve the blastocyst development rate. Fertil. Steril. 2002, 78, $1272-1277$. [CrossRef]

39. Liang, S.; Jin, Y.X.; Yuan, B.; Zhang, J.B.; Kim, N.H. Melatonin enhances the developmental competence of porcine somatic cell nuclear transfer embryos by preventing DNA damage induced by oxidative stress. Sci. Rep. 2017, 7, 11114. [CrossRef]

40. Su, J.; Wang, Y.; Xing, X.; Zhang, L.; Sun, H.; Zhang, Y. Melatonin significantly improves the developmental competence of bovine somatic cell nuclear transfer embryos. J. Pineal Res. 2015, 59, 455-468. [CrossRef]

41. Cui, X.S.; Jeong, Y.J.; Jun, J.H.; Kim, N.H. Insulin-like growth factor-I alters apoptosis related genes and reduces apoptosis in porcine parthenotes developing In Vitro. Theriogenology 2005, 63, 1070-1080. [CrossRef]

42. Loureiro, B.; Oliveira, L.J.; Favoreto, M.G.; Hansen, P.J. Colony-stimulating factor 2 inhibits induction of apoptosis in the bovine preimplantation embryo. Am. J. Reprod. Immunol. 2011, 65, 578-588. [CrossRef] [PubMed] 
43. Sosa, F.; Block, J.; Yao, X.; Hansen, P.J. Determinants of survival of the bovine blastocyst to cryopreservation stress: Treatment with colony stimulating factor 2 during the morula-to-blastocyst transition and embryo sex. CABI Agric. Biosci. 2020, 1, 12. [CrossRef]

44. Chang, H.Y.; Xie, R.X.; Zhang, L.; Fu, L.Z.; Zhang, C.T.; Chen, H.H.; Wang, Z.Q.; Zhang, Y.; Quan, F.S. Overexpression of miR-101-2 in donor cells improves the early development of Holstein cow somatic cell nuclear transfer embryos. J. Dairy Sci. 2019, 102, 4662-4673. [CrossRef]

45. Wang, M.; Gao, Y.; Qu, P.; Qing, S.; Qiao, F.; Zhang, Y.; Mager, J.; Wang, Y. Sperm-borne miR-449b influences cleavage, epigenetic reprogramming and apoptosis of SCNT embryos in bovine. Sci. Rep. 2017, 7, 13403. [CrossRef] [PubMed]

46. Hamazaki, N.; Uesaka, M.; Nakashima, K.; Agata, K.; Imamura, T. Gene activation-associated long noncoding RNAs function in mouse preimplantation development. Development 2015, 142, 910-920. [CrossRef]

47. Deng, W.; Yang, D.; Zhao, B.; Ouyang, Z.; Song, J.; Fan, N.; Liu, Z.; Zhao, Y.; Wu, Q.; Nashun, B.; et al. Use of the 2A peptide for generation of multi-transgenic pigs through a single round of nuclear transfer. PLoS ONE 2011, 6, e19986. [CrossRef]

48. Funahashi, H.; Cantley, T.C.; Day, B.N. Synchronization of meiosis in porcine oocytes by exposure to dibutyryl cyclic adenosine monophosphate improves developmental competence following In Vitro fertilization. Biol. Reprod. 1997, 57, 49-53. [CrossRef]

49. Yoshioka, K.; Suzuki, C.; Tanaka, A.; Anas, I.M.; Iwamura, S. Birth of piglets derived from porcine zygotes cultured in a chemically defined medium. Biol. Reprod. 2002, 66, 112-119. [CrossRef]

50. Picelli, S.; Faridani, O.R.; Bjorklund, A.K.; Winberg, G.; Sagasser, S.; Sandberg, R. Full-length RNA-seq from single cells using Smart-seq2. Nat. Protoc. 2014, 9, 171-181. [CrossRef] [PubMed]

51. Bolger, A.M.; Lohse, M.; Usadel, B. Trimmomatic: A flexible trimmer for Illumina sequence data. Bioinformatics 2014, 30, 2114-2120. [CrossRef]

52. Kim, D.; Pertea, G.; Trapnell, C.; Pimentel, H.; Kelley, R.; Salzberg, S.L. TopHat2: Accurate alignment of transcriptomes in the presence of insertions, deletions and gene fusions. Genome Biol. 2013, 14, R36. [CrossRef]

53. Trapnell, C.; Roberts, A.; Goff, L.; Pertea, G.; Kim, D.; Kelley, D.R.; Pimentel, H.; Salzberg, S.L.; Rinn, J.L.; Pachter, L. Differential gene and transcript expression analysis of RNA-seq experiments with TopHat and Cufflinks. Nat. Protoc. 2012, 7, 562-578. [CrossRef]

54. He, X.; Tan, C.; Li, Z.; Zhao, C.; Shi, J.; Zhou, R.; Wang, X.; Jiang, G.; Cai, G.; Liu, D.; et al. Characterization and comparative analyses of transcriptomes of cloned and In Vivo fertilized porcine pre-implantation embryos. Biol. Open 2019,8 , o39917. [CrossRef]

55. Ao, Z.; Wu, X.; Zhou, J.; Gu, T.; Wang, X.; Shi, J.; Zhao, C.; Cai, G.; Zheng, E.; Liu, D.; et al. Cloned pig fetuses exhibit fatty acid deficiency from impaired placental transport. Mol. Reprod. Dev. 2019, 86, 1569-1581. [CrossRef]

56. Dhanasekaran, S.; Doherty, T.M.; Kenneth, J. Comparison of different standards for real-time PCR-based absolute quantification. J. Immunol. Methods 2010, 354, 34-39. [CrossRef]

57. KEGG PATHWAY: IL-17 Signaling Pathway-Sus Scrofa (Pig). Available online: https://www.kegg.jp/pathway/ssc04657 (accessed on 14 May 2021).

58. KEGG PATHWAY: Apoptosis-Sus Scrofa (Pig). Available online: https:/ /www.kegg.jp/pathway/ssc04210 (accessed on 14 May 2021).

59. Ueda, T.; Kohama, Y.; Kuge, A.; Kido, E.; Sakurai, H. GADD45 family proteins suppress JNK signaling by targeting MKK7. Arch. Biochem. Biophys. 2017, 635, 1-7. [CrossRef]

60. Papa, S.; Zazzeroni, F.; Bubici, C.; Jayawardena, S.; Franzoso, G. Gadd45 beta mediates the NF-kappa B suppression of JNK signalling by targeting MKK7/JNKK2. Nat. Cell Biol. 2004, 6, 146-153. [CrossRef]

61. Schüle, K.M.; Leichsenring, M.; Andreani, T.; Vastolo, V.; Niehrs, C. GADD45 promotes locus-specific DNA demethylation and 2C cycling in embryonic stem cells. Gene. Dev. 2019, 33, 782-798. [CrossRef]

62. Galluzzi, L.; Blomgren, K.; Kroemer, G. Mitochondrial membrane permeabilization in neuronal injury. Nat. Rev. Neurosci. 2009, 10, 481-494. [CrossRef]

63. Nechiporuk, T.; Kurtz, S.E.; Nikolova, O.; Liu, T.; Jones, C.L.; D’Alessandro, A.; Culp-Hill, R.; D’Almeida, A.; Joshi, S.K.; Rosenberg, M.; et al. The TP53 apoptotic network is a primary mediator of resistance to BCL2 inhibition in AML cells. Cancer Discov. 2019, 9, 910-925. [CrossRef]

64. Oyadomari, S.; Mori, M. Roles of CHOP/GADD153 in endoplasmic reticulum stress. Cell Death Differ. 2004, 11, 381-389. [CrossRef]

65. Ashkenazi, A.; Fairbrother, W.J.; Leverson, J.D.; Souers, A.J. From basic apoptosis discoveries to advanced selective BCL-2 family inhibitors. Nat. Rev. Drug Discov. 2017, 16, 273. [CrossRef]

66. Shen, J.; Zhang, Y.; Yu, H.; Shen, B.; Liang, Y.; Jin, R.; Liu, X.; Shi, L.; Cai, X. Role of DUSP1/MKP1 in tumorigenesis, tumor progression and therapy. Cancer Med. 2016, 5, 2061-2068. [CrossRef]

67. Li, H.; Song, M.; Yang, W.; Cao, P.; Zheng, L.; Zuo, Y. A Comparative analysis of single-cell transcriptome identifies reprogramming driver factors for efficiency improvement. Mol. Ther. Nucleic Acids 2020, 19, 1053-1064. [CrossRef]

68. Kong, Q.; Yang, X.; Zhang, H.; Liu, S.; Zhao, J.; Zhang, J.; Weng, X.; Jin, J.; Liu, Z. Lineage specification and pluripotency revealed by transcriptome analysis from oocyte to blastocyst in pig. FASEB J. 2020, 34, 691-705. [CrossRef]

69. Ramos-Ibeas, P.; Sang, F.; Zhu, Q.; Tang, W.; Withey, S.; Klisch, D.; Wood, L.; Loose, M.; Surani, M.A.; Alberio, R. Pluripotency and $\mathrm{X}$ chromosome dynamics revealed in pig pre-gastrulating embryos by single cell analysis. Nat. Commun 2019, 10, 500. [CrossRef] 